Article

\title{
Comparison of SHD and Open-Center Training Systems in Almond Tree Orchards cv. 'Soleta'
}

\author{
José Casanova-Gascón ${ }^{1, *} \mathbb{0}$, Marcos Figueras-Panillo ${ }^{1}$, Ignasi Iglesias-Castellarnau ${ }^{2}$ and \\ Pablo Martín-Ramos ${ }^{1}$ D \\ 1 Instituto Universitario de Investigación en Ciencias Ambientales de Aragón (IUCA), EPS, Universidad de \\ Zaragoza, Carretera de Cuarte s/n, 22071 Huesca, Spain; marcosfigueras95@gmail.com (M.F.-P.); \\ pmr@unizar.es (P.M.-R.) \\ 2 Agromillora Catalana, Plaça Manel Raventós 3-5, St. Sadurní d'Anoia, 08770 Barcelona, Spain; \\ iiglesias@agromillora.com \\ * Correspondence: jcasan@unizar.es
}

Received: 14 November 2019; Accepted: 9 December 2019; Published: 11 December 2019

\begin{abstract}
The increase in the demand for almonds, the development of novel self-fertile and late-flowering varieties, and the establishment of plantations in new irrigated areas have led to significant progress in the productive techniques of almond tree cultivation. One of the most important has been the increase in planting density, due to the development of dwarfing rootstocks. This paper presents a comparison between two training systems with 'Soleta' almond cultivar: a super high density (SHD) system using Rootpac-20 dwarfing rootstock versus an open-center training system using GF-677 rootstock. To this end, several parameters related to chlorophyll content (fluorescence and SPAD) and light interception (from photosynthetically active radiation (PAR) measurements) were monitored throughout two vegetative cycles, and other productive conditions (flowering, fruit set and production) were tracked at specific times of the cycle. The open-center system resulted in higher PAR interception than the SHD system, but also in the presence of poorly illuminated fractions of the canopy. Differences were observed between both systems in terms of average fruit weight and yield per canopy volume. Lower yields were obtained in SHD system than in open-center, which may be significantly increased by adapting the inter-row spacing. However, the degree of efficiency in the use of resources or productive inputs, such as irrigation, was favorable to the new SHD training system, so its potential to become a reference system in modern plantations (using over-the-row harvesters similar to those used for vine and olive trees) seems promising.
\end{abstract}

Keywords: Prunus dulcis; planting systems; high density; efficiency; 2D; super-efficient system (SES)

\section{Introduction}

The USA, and more specifically California, leads the world production of almonds, with an $80 \%$ market share. However, as far as crop area is concerned, the European Union concentrates $39 \%$ of the world almond-tree dedicated area, $84 \%$ of which is located in Spain, which hence accounts for almost one third of the world area [1]. These over 633,000 ha are mainly concentrated in the Mediterranean area: in Aragon (20\%), Catalonia (7\%), Valencian Community (17\%), Murcia (12\%), Andalusia (30\%) and Castilla la Mancha (8\%) [2].

In just a few years, in Spain the almond industry has gone from being a marginal crop grown in poor and arid soils to represent an alternative production to the traditional ones of deciduous fruit, cereals or citrus. This change in production management has caused the almond tree to currently offer a 20-25\% higher profitability than cereals or olive trees for the same farm [3]. At the same time, almond consumption has markedly increased, as world demand has grown at a rate of $5 \%$ per year [3]. 
In Spain, other favorable factors have joined the advantageous international situation, such as the impulse of new late-flowering varieties, barely exposed to spring frosts and self-fertile varieties (less exposed to climatic conditions during flowering), and the introduction of irrigation.

The behavior of very high-density or super-intensive plantations (with over 2000 trees/ha) started to be investigated a decade ago in almond and 25 years ago in olive trees [4,5]. Less vigorous rootstocks, training and pruning systems appropriate to this system and high-efficiency over-the-row harvesters (similar to those used for vine or olive trees) have been assessed [6]. This combination of innovations makes it possible to think in a new productive model similar to the one used in deciduous fruit crops, the two-dimensional (2D), super high density (SHD) or sustainable and efficient system (SES) model [7], based on productive walls and not on individual trees and on the use of dwarfing patterns [7-10]. These patterns make it possible to have smaller and more efficient canopies, and at the same time reduce production costs due to better efficiency of water and fertilizers, better accessibility to the canopy and easier mechanization [11]. Hence, although this type of plantation is in an experimental phase and its medium- and long-term behavior is still unknown [6], it may be foreseen that this training system may be able to offer the same advantages, already proven, attained for aforementioned crops (i.e., vine on trellis and SHD olive groves) and for fruit trees $[10,12,13]$. Some of these advantages include an increase in the effectiveness of phytosanitary treatments and in management, water savings in irrigation, minimization of soil maintenance, early yields, possibility of harvesting with over-the-row machines and robotic harvest of deciduous fruits, reduction of necessary labor and improvement of the profitability of the crop [12,13].

Furthermore, the implantation of these novel training systems can also have a significant impact on light distribution and light interception in the canopy [14-16]. For instance, in certain traditional training systems, the innermost region of the canopy can present problems with "sink leaves" or incorrectly illuminated organs [17], which would be problematic, given that the light environment in a particular area in the tree canopy is known to influence leaf characteristics as well as flowering and fruit production $[18,19]$. In the almond tree, the regularity of the production requires the formation of a large number of flowers each year (high floral density) and their adequate pollination in order to obtain an acceptable setting and, in turn, a profitable harvest [20-22]. Moreover, in mature almond trees, yields reflect in a large measure the number of fruit and fruit-bearing spurs, and spur survival is reduced by shading of lower or interior branches, an indirect result of excessive vegetative growth [23].

Since, to the best of the authors' knowledge, the influence of the SHD training system on almond trees has not been reported in the literature, the aim of the present study has been to fill this knowledge gap. The phenological stages throughout the vegetative cycle have been monitored, comparing two production systems (conventional vs. SHD) during two growing seasons through various productive parameters, and the influence of canopy architecture on light interception has been investigated. The obtained results should be useful for feasibility studies related to the implantation of the SHD system in future plantations in the Mediterranean region.

\section{Material and Methods}

\subsection{Location}

The study was carried out in 2018 and 2019 in an experimental almond tree plantation in the "Mas d'en Félis" farm (Figure S1), in the municipality of La Granja d'Escarp, Lleida, Spain (polygon 5, plot 592; coordinates $41^{\circ} 24^{\prime} 41.7^{\prime \prime} \mathrm{N} 0^{\circ} 22^{\prime} 39.4^{\prime \prime} \mathrm{E} ; 78 \mathrm{~m}$ above sea level). Almond trees were planted in both systems at the beginning of 2010. For the SHD plantation, the rows were oriented in north-south direction as far as the topography of the plot allowed it.

The soil can be classified as Xeric Torriorthent, and basic information from the soils analyses is summarized in Table 1. The physicochemical properties are typical of most of the soils located in the lowlands of Ebro Valley (NE Spain). The most relevant traits were the high $\mathrm{pH}$ and $\mathrm{CaCO}_{3}$ eq. As a consequence, it is a common practice to supply iron chelate and others chelated nutrients (e.g., $\mathrm{Zn}$ and 
$\mathrm{Mn}$ ) through the drip irrigation system, minimizing the effect of differences in the excess soluble $\mathrm{Ca}$ in the soil. Differences in $\mathrm{N}^{-\mathrm{NO}_{3}}$, tentatively ascribed to fertilization leftovers from previous season, should not have a significant effect on the reported results (e.g., on vigor), given that a drip irrigation system was used to supply the nutrients in both tested systems, which would mask aforementioned differences to a large extent.

Table 1. Soil physicochemical properties of the two plots at two depths $(0-30$ and $30-60 \mathrm{~cm})$. Concentrations are expressed in dry soil weight.

\begin{tabular}{|c|c|c|c|c|}
\hline \multirow{2}{*}{ Parameter } & \multicolumn{2}{|c|}{ Super High Density (SHD) } & \multicolumn{2}{|c|}{ Open-Center } \\
\hline & $0-30 \mathrm{~cm}$ & $30-60 \mathrm{~cm}$ & $0-30 \mathrm{~cm}$ & $30-60 \mathrm{~cm}$ \\
\hline pH $\left(\right.$ ext. 1:2.5 $\left.\mathrm{H}_{2} \mathrm{O}\right)$ & 7.97 & 8.02 & 7.90 & 7.83 \\
\hline EC $25^{\circ} \mathrm{C}\left(\right.$ ext. $\left.1: 5 \mathrm{H}_{2} \mathrm{O}\right), \mathrm{dS} / \mathrm{m}$ & 2.49 & 2.40 & 2.61 & 2.51 \\
\hline $\mathrm{OM}(\mathrm{W} \& \mathrm{~B}), \%$ & 1.92 & 1.13 & 1.42 & 1.28 \\
\hline $\mathrm{CaCO}_{3}$ eq., $\%$ & 28 & 29 & 29 & 32 \\
\hline $\mathrm{N}-\mathrm{NO}_{3}, \mathrm{mg} / \mathrm{kg}$ & 172 & 164.9 & 95.3 & 71.5 \\
\hline $\mathrm{P}($ Olsen $), \mathrm{mg} / \mathrm{kg}$ & 23 & $<5.0$ & 11.3 & 5.5 \\
\hline $\mathrm{K}$ (ammonium acetate ext.), $\mathrm{mg} / \mathrm{kg}$ & 256 & 96 & 334 & 125 \\
\hline $\mathrm{Ca}$ (ammonium acetate ext.), $\mathrm{mg} / \mathrm{kg}$ & 9090 & 9619 & 3325,2 & 3851,9 \\
\hline Particle-size class (USDA) & Silty clay loam & Silty clay loam & Silt loam & Silt loam \\
\hline Active lime, $\%$ & 7 & 7 & 6 & 6 \\
\hline
\end{tabular}

EC and $\mathrm{OM}(\mathrm{W} \& \mathrm{~B})$ stand for electrical conductivity and organic matter determined by Walkley-Black method, respectively.

\subsection{Plant Material and Tree Spacing}

The two training systems were tested using 'Soleta' cultivar ('Blanquerna' $\times$ 'Belle d'Aurons'; acronym F-4-10, clone 503, registration number in the OEW 20054616), obtained by CITA (Aragón, Spain). It is an auto-fertile, late flowering, medium-late ripening cultivar, with an interesting quality and production. The interested reader may find further information on this cultivar in [24-27].

Combinations of 'Soleta' with two rootstocks with different planting distances and training systems were compared. On the one hand, trees grafted onto Rootpac-20 rootstock (Agromillora Catalana, Spain), with a $4 \mathrm{~m} \times 1 \mathrm{~m}$ planting distance (2500 trees/ha), with an anarchic hedgerow formation system but maintaining in general the central leader $(2.70 \mathrm{~m}$ high, $0.90 \mathrm{~m}$ wide and with a height at the cross of $0.5 \mathrm{~m}$ ). On the other hand, trees grafted onto GFF-677 rootstock (INRA, Montpellier, France), with a $6 \mathrm{~m} \times 6 \mathrm{~m}$ planting distance of (278 trees/ha), with an open-center formation system (tree dimensions of ca. $4.85 \mathrm{~m}$ high, $4.9 \mathrm{~m}$ maximum diameter and height at the cross of $1.3 \mathrm{~m}$ ).

\subsection{Cultural Practices}

High frequency localized irrigation was used, with applied doses of ca. $6700 \mathrm{~m}^{3} / \mathrm{ha}$ in the SHD system and ca. $7900 \mathrm{~m}^{3} /$ ha in the open-center formation system, given that the rainfall in the area during the growing seasons were lower than $300 \mathrm{~mm}$. Concerning fertilization, the characteristics of the soil were taken into account, and 240 inorganic $\mathrm{N}$ units, $60 \mathrm{P}_{2} \mathrm{O}_{5}$ units and $190 \mathrm{~K}_{2} \mathrm{O}$ units were applied per ha and year through the fertigation system.

Regarding soil management, the plantation rows were kept clean of weeds through the application of herbicides, while the streets remained in non-tillage, and weed removal was done through strimmer passes. Eight phytosanitary treatments were applied with a tractor-mounted atomizer, carried out according to the recommendations of the farm advisor, and in good agreement with the integrated pest management guidance provided by the Agriculture Department of the Generalitat de Cataluña regional government.

Both training and production pruning were carried out mechanically, with a disk machine. Harvesting was also carried out in a mechanized way for the two types of training system, albeit using 
different equipment: the hedgerows were harvested using an over-the-row machine, while in the open-center trees a shaker with an umbrella was used instead.

\subsection{Experimental Design}

In the case of SHD trees, because of their small volume, five experimental units of three consecutive trees/unit were monitored. On the other hand, in the case of open-center trees, three experimental units of one tree/unit were chosen. The reason behind the choice of these different experimental designs was the effort involved in the flower and fruit counting, discussed below, which were conducted for the entire trees (instead of using a few branches for estimation purposes).

\subsection{Flower Counting, Fruit Counting and Harvest}

In March, the total number of flowers of each of the experimental unit was manually counted during the phenological state $\mathrm{D}$ (at the time in which petals are seen), and in July a fruit counting was carried out to determine the fruit set rate, defined as the percentage of flowers that persist until ripening, and which depends on the viability of pollen and on the available carbohydrates, which may vary from one year to another [28]. An advanced date was chosen for this counting to avoid errors resulting from fruits purged by the tree that do not mature (such natural fruit drop early in the season would work as a mechanism that enhances spur survival [29]). In September, the fruits were collected for each of the experimental units of both training systems, and homogeneous samples of $1 \mathrm{~kg}$ of almonds with hull were extracted from each of the replicates. Almond in shell weights (after hulling, expressed in g), kernel weights (after shelling, expressed in g), kernel yields (in \%) and humidity were determined. The results were also expressed as almond fresh fruit yields, almond in shell yields and kernel yields in $\mathrm{kg} / \mathrm{tree}$ and in $\mathrm{kg} / \mathrm{ha}$. The latter was estimated considering the planting densities indicated in Section 2.2. For the calculation of the yield per canopy volume (in $\mathrm{g}$ of $\mathrm{kernel} / \mathrm{m}^{3}$ ), the canopy volume was estimated by approximating the tree shape to an ellipsoid in the case of open-center trees [30] and to a rectangular parallelepiped in the case of SHD trees. Yield efficiency (in $\mathrm{g}$ of kernel $/ \mathrm{cm}^{2}$ ) was determined by dividing kernel weights per tree by the trunk cross-sectional area (TCSA) measured $20 \mathrm{~cm}$ above the scion.

\subsection{Equipment and Measurements}

Fluorescence measurements were performed with a Handy PEA (Plant Efficiency Analyzer; Hansatech Instruments, Pentney, Norfolk, UK), on a bimonthly basis since the end of May till the beginning of September. Ten measurements were taken for each block in the case of trees in hedgerow formation, while 17 measurements were taken for each of the open-center almond trees.

Leaf chlorophyll status was also monitored bimonthly throughout the entire vegetative period (May-September). A SPAD-502 m (Minolta, Osaka, Japan) was used. In SHD trees, 20 values were collected for each block, equally distributed between east and west orientations. In the open-center trees, measurements were distributed along the entire perimeter of the tree, obtaining 30 measurements per tree and date.

Photosynthetically active radiation measurements were carried out with an AccuPAR LP-80 linear ceptometer (Decagon Devices, Pullman, WA, USA), on a bimonthly basis, at solar noon. For hedgerow trees, nine measurements were carried out per experimental unit. For the open-center trees, 21 measurements were taken for each individual, distributed in three lines with seven measurements per line (see Figure S2). From the measurements, two indices were determined: the percentage of intercepted radiation (LI) and the LAI (leaf area index) [31]. In addition, to gain insight on the presence of shaded canopy regions (in which light levels may be below threshold values for the sequential steps of shoot growth, floral initiation, flowering, fruit formation and fruit filling [32]), tempo-spatial photosynthetically active radiation (PAR) measurements were also conducted in both systems at different times (every 60 or $90 \mathrm{~min}$, from 08:00 until 18:00/18:30, depending on the training system) 
on three dates (at the end of June, July and August) in the 2019 growing season. A scheme of how measurements were conducted is presented in Figure S3.

\subsection{Statistical Analyses}

Statistical analyses were carried out with IBM (Armonk, NY, USA) SPSS Statistics v.22 software. Prior to the analyses, the assumptions of independence, normality and homoscedasticity were checked for all groups. Since the data did not met the normality requirement, checked with a Shapiro-Wilk test, and the homoscedasticity requirement, checked with a Bartlett's test, Kruskal-Wallis non-parametric test was used. Conover-Iman test was chosen for post hoc multiple pairwise comparisons of the agronomical characteristics and fruit quality parameters. Productive parameters data was also subjected to principal component analysis (PCA) with the Varimax rotation method with Kaiser normalization. In the PCA, the components that accounted for most of the variance were selected, and those that contained only a small percentage of the variance of the original data were removed.

\section{Results}

\subsection{Fluorescence and Chlorophyll (SPAD) Measurements}

Fluorescence analysis (i.e., measurement of variable fluorescence $(\mathrm{Fv})$ and estimation of the maximum quantum efficiency of PSII photochemistry ( $\mathrm{Fv} / \mathrm{Fm})$ ) did not yield significant differences between the SHD and the open-center trees.

The results of the SPAD measurements were also similar for open-center and hedgerow trees throughout the study period, in both years (Figure 1 shows SPAD data for 2018 growing season). No significant differences were detected between SPAD values in the 2018 and 2019 growing seasons either.

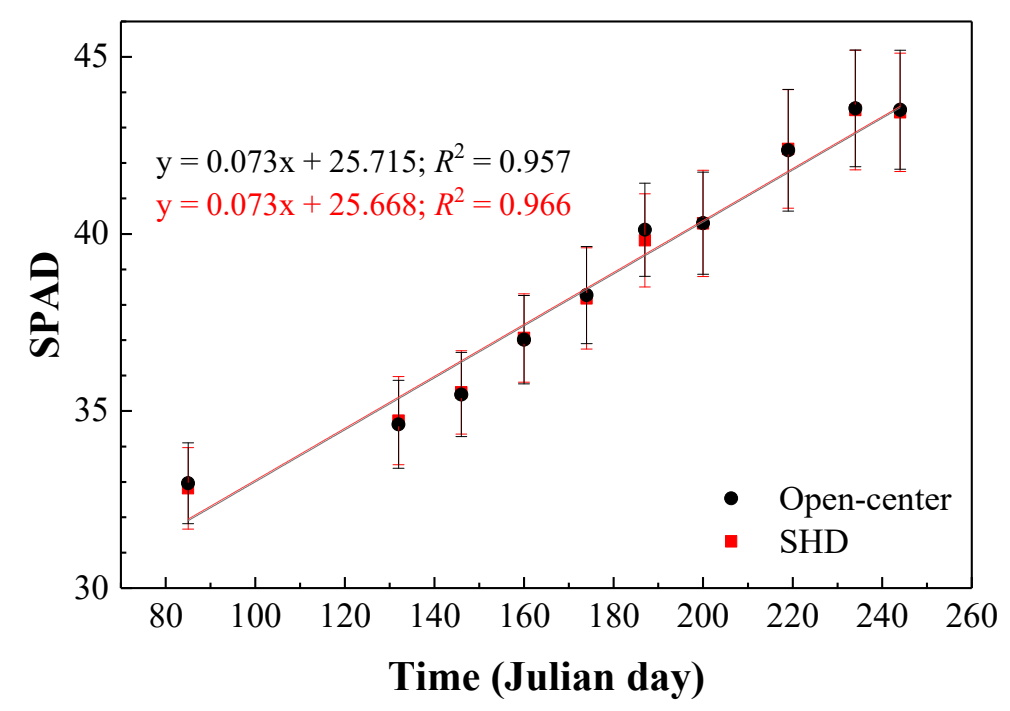

Figure 1. Analysis of the temporal evolution of the SPAD measurements for the 'Soleta' cultivar almond trees using super high density (SHD; red) and open-center (black) training systems in 2018 growing season. The $x$-axis shows the day of the year.

\subsection{Photosynthetically Active Radiation}

In both growing seasons, in the SHD system, noticeable differences were observed between the outer part and the inner part of the hedgerow (Figure 2a,b), both in terms of percentage of light interception (LI) and leaf area index (LAI). In the open-center trees (Figure 2c,d), differences in LI and LAI were observed as a function of the region under the canopy (innermost, intermediate and outermost). Oscillations should be mainly ascribed to the variability of incident sunlight, affected by partly cloudy days $[33,34]$, which would be more evident in the SHD system because its smaller 
canopy does not cover the full space assigned. The impact of mechanical pruning conducted in SHD twice a year (at the end of May and October) to keep the canopy volume controlled should not have a major influence on LI or LAI variation, due to the mid-low vigor of the SHD trees.
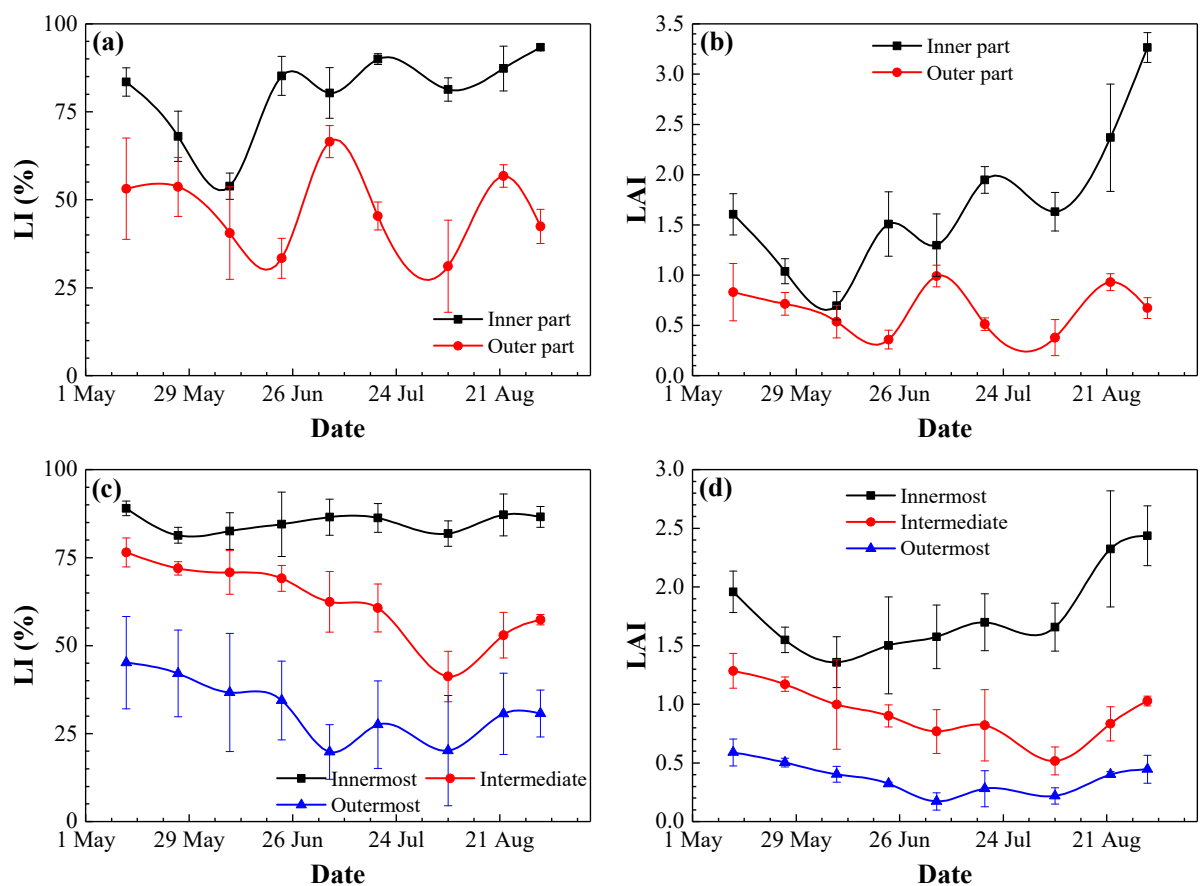

Figure 2. Evolution of light interception (LI; a,c) and leaf area index (LAI; b,d) in SHD almond trees $(\mathbf{a}, \mathbf{b})$ and open-center trees $(\mathbf{c}, \mathbf{d})$ throughout the growing season in 2018. Photosynthetically active radiation (PAR) measurements conducted at solar noon.

The results from tempo-spatial LI measurements conducted in both systems on three dates in the 2019 growing season are shown in Figure 3. PAR measurements, which may be useful for estimating the photosynthetic radiation use efficiency [35] or yield [35], are also shown in Figures S4 and S5.
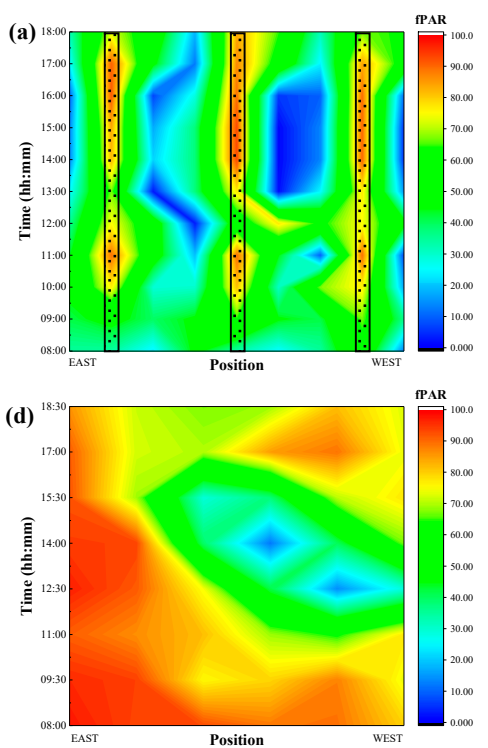
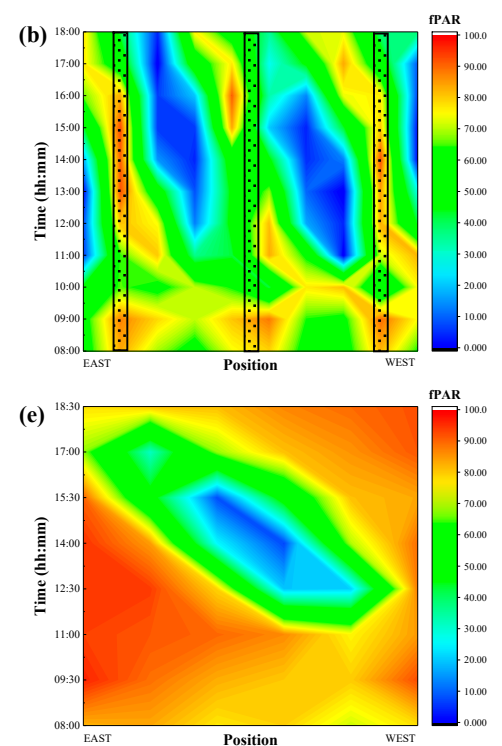
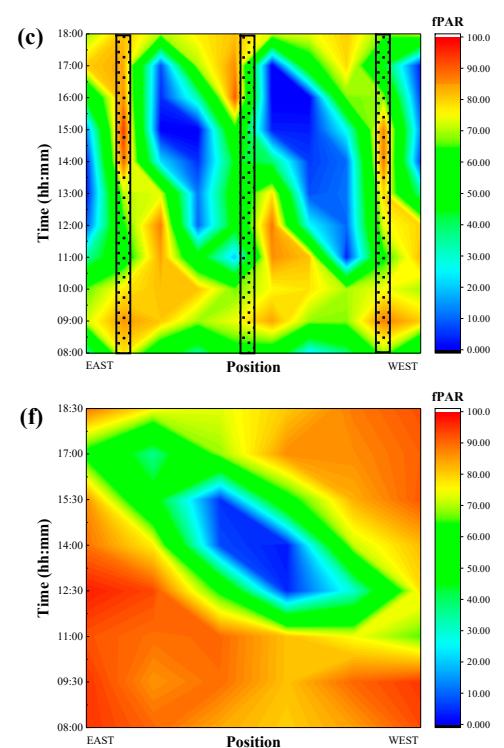

Figure 3. Evolution of LI in the SHD $(\mathbf{a}-\mathbf{c})$ and open-center trained trees $(\mathbf{d}-\mathbf{f})$ along a day in three different dates: 24 June (a,d), 25 July (b,e) and 31 August 2019 (c,f). The hedgerows are represented as semi-transparent rectangles. In the case of open-center trees, only the space between two consecutive trees is shown (trunks correspond to the beginning and the end of the $x$-axis). 
Taking into consideration the full data set of PAR recorded in 2019, we calculated the mean data for each point measured between two adjacent inter-rows in three parallel and consecutive determination lines, for each solar time (from 08:00 to 18:30), and across the three dates (24 June, 25 July and 31 August 2019). Results obtained are represented in Figure 4. The effect of training system was very clear: the open-center resulted in higher PAR interception at all times and on the three dates than the SHD. This is due to its larger and three-dimensional canopy compared with the vertical and bidimensional canopy wall of the hedgerow-based system. Average percentages of light interception, considering all hours and dates, were $73.5 \%$ and $54.4 \%$ for open-center and SHD, respectively.

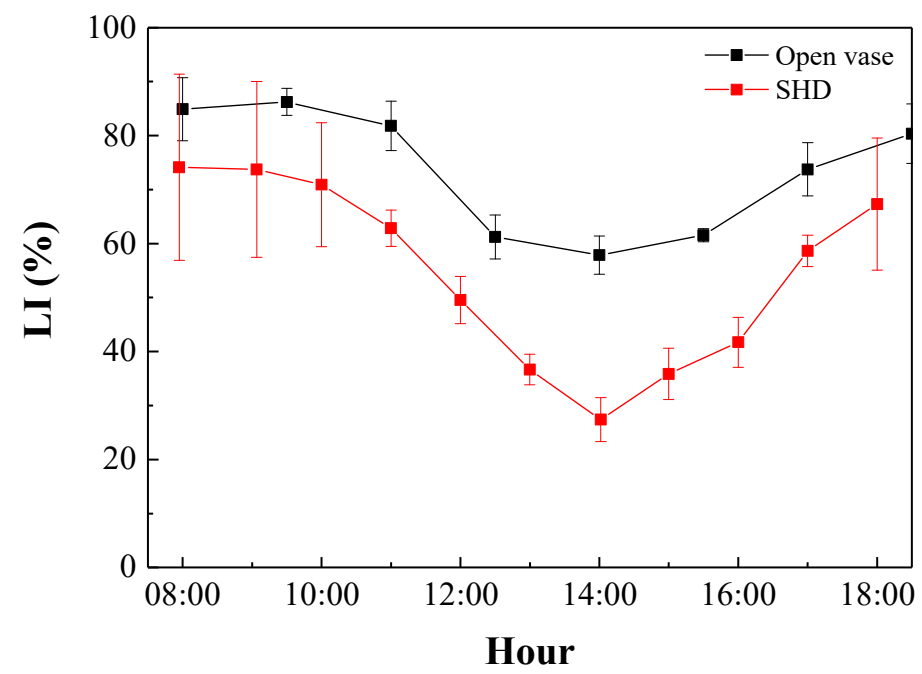

Figure 4. Light interception as \% above canopy available PAR (LI) in the SHD and open-center trained trees along a day (solar time). Average values across the three dates \pm standard deviations are shown.

\subsection{Productive Parameters}

A summary of number of flowers, number of fruits, fruit set, productive parameters, yield efficiency and fruit quality obtained in this study is presented in Table 2.

Table 2. Effect of the training system on the agronomical characteristics and fruit quality of 'Soleta' cultivar in 2018 and 2019 growing seasons at Finca Mas d'en Felix (La Granja d'Escarp, Lleida, Spain). Values are expressed as median \pm interquartile range (IQR).

\begin{tabular}{|c|c|c|c|c|c|}
\hline Parameter & \multicolumn{2}{|c|}{2018} & \multicolumn{2}{|c|}{2019} & Kruskal-Wallis \\
\hline No. flowers/tree & $2134 \pm 1120 b$ & $26918 \pm 6949 a$ & $703 \pm 920 c$ & $10608 \pm 3723 \mathrm{ab}$ & $<0.0001$ \\
\hline Fruit set rate $(\%)$ & $22.8 \pm 10.3 b$ & $20.9 \pm 5.6 \mathrm{ab}$ & $42.0 \pm 21.8 \mathrm{a}$ & $21.5 \pm 3.1 \mathrm{ab}$ & 0.016 \\
\hline Almond fresh fruit yield (kg/tree) & $3.30 \pm 0.91 b$ & $78.82 \pm 22.03 \mathrm{a}$ & $3.00 \pm 1.73 b$ & $53.00 \pm 8.00 \mathrm{a}$ & 0.001 \\
\hline Almond in shell yield (kg/tree) & $1.77 \pm 0.51 b$ & $34.66 \pm 4.85 \mathrm{a}$ & $1.69 \pm 1.22 b$ & $24.92 \pm 7.64 \mathrm{a}$ & 0.002 \\
\hline Kernel yield $(\mathrm{kg} / \mathrm{ha})^{*}$ & 1575 & 2847 & 1325 & 1719 & \\
\hline Almond in shell weight $(\mathrm{g})$ & $2.38 \pm 0.16 b$ & $3.32 \pm 0.19 a$ & $3.53 \pm 1.09 a$ & $4.10 \pm 0.25 a$ & $<0.0001$ \\
\hline Kernel weight $(\mathrm{g})$ & $0.93 \pm 0.03 b$ & $1.18 \pm 0.08 \mathrm{a}$ & $1.11 \pm 0.30 \mathrm{a}$ & $1.12 \pm 0.08 \mathrm{a}$ & $<0.0001$ \\
\hline Kernel yield (\%) & $38.33 \pm 1.61 \mathrm{a}$ & $35.66 \pm 0.40 b$ & $31.45 \pm 1.39 c$ & $29.52 \pm 1.27 \mathrm{~d}$ & $<0.0001$ \\
\hline Canopy volume $\left(\mathrm{m}^{3}\right)$ & $2.05 \mathrm{~d}$ & $59.80 \pm 1.25 \mathrm{a}$ & $2.25 \mathrm{c}$ & $58.40 \pm 1.70 \mathrm{~b}$ & $<0.0001$ \\
\hline Yield per canopy volume (g kernel $/ \mathrm{m}^{3}$ ) & $306.9 \pm 31.6 \mathrm{a}$ & $171.4 \pm 23.2 \mathrm{~b}$ & $233.9 \pm 185.3 \mathrm{ab}$ & $106.0 \pm 34.2 \mathrm{~b}$ & $<0.0001$ \\
\hline
\end{tabular}

TCSA: truck cross-sectional area. ${ }^{*}$ Estimated from median values. Values with the same letter in the same row are not statistically different at $p \leq 0.05$. 
The training system clearly affected the agronomical performance of 'Soleta' cultivar, as reported in Table 2, mainly because large differences were recorded in tree volume canopy, as a consequence of differences in the TCSA between the two systems (if TCSA values in 2019 were interpreted as a vigor index, that of SHD trees with Rootpac- 20 rootstock was only $17 \%$ of that of open-center trees with GF-677). Thus, the number of flowers and fruits were statistically different in both years, but not the fruit set rates. Similarly, kernel yield per ha was higher in the open-center system in both years because of the significant differences in canopy volume, resulting in more light interception (although it should be taken into consideration that, as discussed below, the spacing used in this first experimental SHD plot differs from the one currently used in commercial SHD orchards). Kernel weight was only affected by the training system in 2018. Kernel yield (\%) showed better values in SHD compared to open-vase.

The results from PCA are summarized in Figure 5 and Figure S6 (correlation circles). The first, second and third component explained $55.23 \%, 28.35 \%$ and $7.75 \%$ of the variance, respectively (i.e., the cumulative explained variance was $91.34 \%$ ). The parameters included in each component are indicated in Figure 5 (left). The strongest underlying trend in the feature set (component 1 ) was the "production" and that the second strongest underlying trend (component 2) was the "fruit" (weight for both almond in shell and kernel, and kernel yield). The third strongest underlying trend (component 3), uncorrelated with both components 1 and 2, was the fruit setting rate (Figure 5), which would depend on a "cultivar $\times$ year interaction" (alternate bearing, climatic conditions, etc.). An unexpected result from the PCA analysis was that canopy volume and yield per canopy volume parameters were enclosed in different component sets.

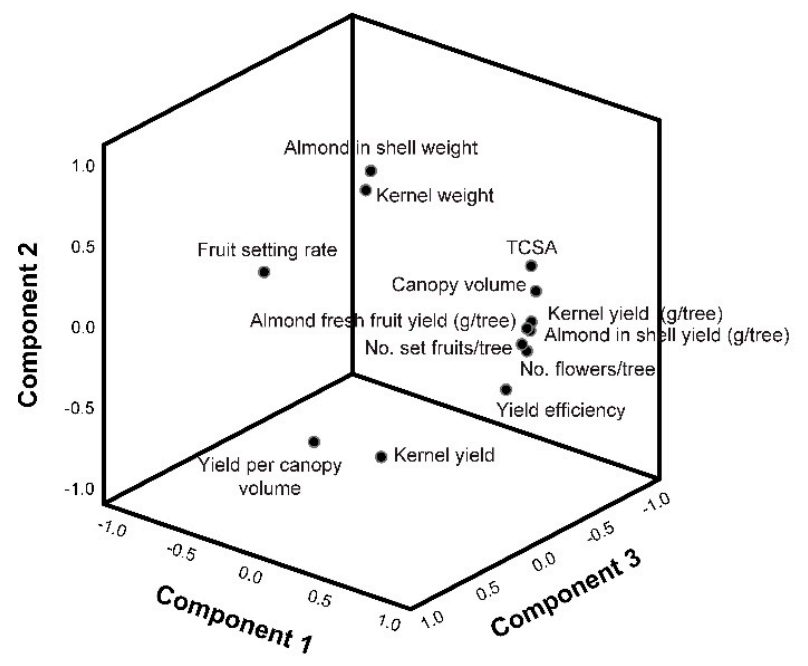

(a)

\begin{tabular}{|c|c|c|c|}
\hline \multirow{2}{*}{ Parameter } & \multicolumn{3}{|c|}{ Component } \\
\hline & 1 & 2 & 3 \\
\hline Kernel yield (g/tree) & 0.982 & & \\
\hline No. set fruits/tree & 0.976 & & \\
\hline No. flowers/tree & 0.973 & & \\
\hline Almond fresh fruit yield (g/tree) & 0.971 & & \\
\hline Almond in shell yield (g/tree) & 0.968 & & \\
\hline Yield efficiency $\left(\mathrm{g} / \mathrm{cm}^{2}\right)$ & 0.955 & & \\
\hline Canopy volume $\left(\mathrm{m}^{3}\right)$ & 0.892 & & \\
\hline TCSA $\left(\mathrm{cm}^{2}\right)$ & 0.757 & & \\
\hline Almond in shell weight (g) & & 0.952 & \\
\hline Kernel yield (\%) & & -0.931 & \\
\hline Kernel weight (g) & & 0.873 & \\
\hline Yield per canopy volume $\left(\mathrm{g} / \mathrm{m}^{3}\right)$ & & -0.795 & \\
\hline Fruit setting rate & & & 0.743 \\
\hline
\end{tabular}

(b)

Figure 5. Principal component analysis (PCA) component plot in rotated space (a) and rotated component matrix (b), considering mean values of two growing seasons (2018 and 2019).

In any case, PCA successfully found linear combinations of the different markers, which separated out different clusters (Figure 6) corresponding to different training systems (open-center and SHD) and growing seasons (2018 and 2019). 


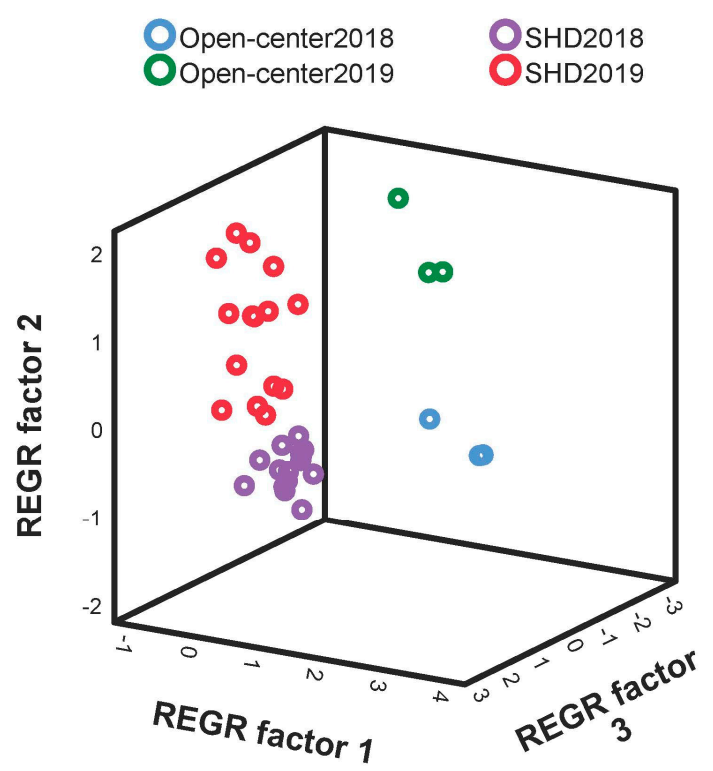

Figure 6. 3D score plot of the PCA for the two training systems (open-center and SHD) and two growing seasons (2018 and 2019).

\section{Discussion}

Fluorescence and SPAD measurements indicated that the state of the trees' health was adequate for both training systems. Fv/Fm values, which provide an estimation of the maximum quantum efficiency of PSII photochemistry, were indicative of the absence of environmental stress in the trees $(\mathrm{Fv} / \mathrm{Fm}>0.8)$ in all cases and in both growing seasons (2018 and 2019), and were similar to those reported by Ranjbarfordoei et al. [36]. Regarding the SPAD measurements, the obtained values were consistent with those of López-López et al. [37] and Erdal et al. [38], and pointed to a constant increase in chlorophyll concentration in leaves during the vegetative cycle, with similar concentrations for both rootstocks (and training systems) and in both growing seasons.

It should be clarified that in this study no adaptation problems of Rootpac-20 to Mediterranean soil conditions were detected, in contrast with the findings of other authors. For instance, Ben Yahmed et al. [39] found Fv/Fm values lower than 0.52 for Rootpac-20 rootstock, suggesting that this rootstock could influence the efficiency of the PSII, and would present a lower tolerance, lower photosynthetic capacity and lower efficiency than GF-677 rootstock. In the same line, Jiménez et al. [40] obtained lower concentrations of chlorophyll for Rootpac-20 than for GF-677.

In relation to the PAR measurements, the obtained average percentages of light interception $(73.5 \%$ and $54.4 \%$ for open-center and SHD, respectively), considering all hours and dates, were in agreement with those reported by Iglesias [9] when comparing different training systems in 'O'Henry' peach cultivar. However, in that case, the Double Y, similar to the open-center, intercepted $12 \%$ more light (considering all hours along a day) than vertical palmette.

Although it was not possible to compare the two systems in terms of light interception due to its dependence on the geometry of the tree, it is worth noting that parts of the canopy in which the light interception was very high were detected for the open-center training system in both years. Similar results were reported by Iglesias [9] when comparing volumetric and planar training systems in peach, due to the lack of light availability in the inner canopy of the trees, negatively affecting fruit size and fruit color.

For maximum productivity, all foliage must be illuminated above threshold values (in the range $20-30 \%$ of incident radiation) for the critical step in the shoot growth-floral initiation-flowering-fruit formation-fruit filling reproductive sequence [32,41]. In view of the tempo-spatial LI data (Figure 3), the open-center trained trees intercepted over $80 \%$ of the incident radiation in many areas throughout the day, so the presence of unproductive regions in the tree canopy would be confirmed [41], resulting 
in an incorrect "light" nutrition of the fruits. As noted by Socias i Company et al. [42], if tree canopies are allowed to become too dense, the inner parts will become so shaded that the leaves can no longer carry on an appreciable amount of photosynthesis. Those interior leaves will then contribute less energy than needed by the fruitwood to which they are attached, and eventually this fruitwood will die. On the other hand, in the SHD system trees, the walls of the hedgerow would have appropriate LI values all throughout the day. Excessive illumination (with an associated temperature increase that would lower the efficiency of the PSII) was only registered at central hours of the day in some inner regions of the hedgerow.

If LI average values were considered (Figure 4) instead, the LI attained by the SHD system (ca. $55 \%)$ would be sufficient: the photosynthetic apparatus of most almond leaves is 'light-saturated' at approximately one-half of full sunlight, in such a way that when the light level is approximately one-half the intensity found at solar noon, the rate of photosynthesis is already at maximum [42].

Concerning the productive parameters, a large variability in the number of flowers and set fruits per tree was found, revealing both the heterogeneity between individuals within each system and significant differences from one year to another. In this regard, it is worth noting that almond trees are prone to an alternate-bearing pattern (i.e., previous year fruit bearing has a negative impact on subsequent year flowering), which can be more or less pronounced depending on the specific cultivar. The sensitivity of some varieties depends to a large extent on their productive load [21,43-45]. Maximization of the yield per tree can have a negative impact on the distribution of nutrients among the different parts of the tree, due to imbalances between vegetative growth and floral differentiation [46,47]. In addition, the effect of rainfall on yield cannot be excluded [48]. Leaf nitrogen content (not monitored in this work), has been proposed as a good predictor of yield variation over periods of two or three years by Zarate-Valdez et al. [49].

Fruit set rates in the open-center trees were similar in both growing seasons, and were in good agreement with those reported by Tombesi et al. [50], who studied the setting rate in an open-center plantation with a density similar to that of this study, with a high variability among individuals and between different years, ranging from 18.4 to $36.0 \%$. However, Kodad et al. [51] obtained significantly lower fruit setting rates, with values of $16.6 \% \pm 6.4 \%$ and $17.3 \% \pm 6.6 \%$ in two consecutive years.

In connection with the setting rate in the SHD trees, although it was similar to that of the open-center trees in 2018, in 2019 it was extraordinarily high (over 40\%). This can be justified by the very low number of flowers (approximately one third of those in the previous growing season). This hypothesis would be further supported by the fact that the fruit set per tree were much more similar (albeit statistically different). In any case, yield would still be seriously affected, provided that increased relative fruit set when floral densities were low does not compensate for lower numbers of flowers [50]. As noted by Tombesi et al. [50], overall tree yield among years would be more sensitive to total number of flowers on a tree rather than relative fruit set.

The almond fresh fruit yields of complete fruit (with hull) per tree were very similar in the SHD trees, while in the open-center trees there were notable differences between growing seasons (although not statistically significant due to the large IQRs). The same situation was repeated for the almond in shell and the kernel yields per tree, although in the latter case the differences between open-center trees in 2018 and 2019 were statistically significant. The almond in shell yields per tree in the open-center training system were higher (34.66 and $24.92 \mathrm{~kg} /$ tree in 2018 and 2019, respectively) than those reported by Puebla Arias et al. [52,53] (13.0 and $12.78 \mathrm{~kg} /$ tree in 2015 and 2016, respectively).

The almond in shell and kernel yields per ha was higher in the open-center than in the SHD system. In the second, third and fifth year after plantation, kernel yields of 450, 1011 and $1734 \mathrm{~kg} / \mathrm{ha}$ were estimated for the same orchard [54]. For comparison purposes, for almond trees of the same cultivar ('Soleta') and of the same age with an open-center training system, Méndez [55] reported remarkably lower kernel yields, in the $814-1330 \mathrm{~kg} / \mathrm{ha}$ range (which would also be lower than those obtained for the SHD system in this study). Puebla Arias et al. [52,53] reported kernel yields of 1476 and $1004 \mathrm{~kg} / \mathrm{ha}$ for trees of approximately the same age and with the same planting density. According 
to CITA (who developed the cultivar), the potential crop for almond in shell would be $4017 \mathrm{~kg} / \mathrm{ha}$ and the kernel yield would be $1095 \mathrm{~kg} / \mathrm{ha}$ (for a $6 \mathrm{~m} \times 7 \mathrm{~m}$ spacing) [25].

In relation to the average weight of the almonds in shell, Socias i Company et al. [26] obtained an average weight for 'Soleta' cultivar of $3.63 \mathrm{~g}$. In this study, the weights were higher for the open-center training system than for the SHD system in both growing seasons. Whereas in 2019 the almond in shell weights were similar or higher than those reported by Socias i Company, in 2018 the weight for the SHD system was significantly lower. The value obtained in 2019 in open-center trees can be attributed to the lower number of set fruits per tree vs. 2018 (4078 vs. 2286).

Concerning the kernel weight values, in the $0.93-1.18 \mathrm{~g} / \mathrm{kernel}$ range, they were lower than those reported by Socias i Company et al. [26] (1.27 g/kernel) and Méndez [55] (1.26 g/kernel). Kernel weights were more homogeneous in 2019 than in 2018, and in 2018 the ones from open-center almond trees were significantly larger than those from SHD trees. This could be explained by the effect of rootstock. Lordan et al. [56] reported larger fruit size of 'Marinada' and 'Vairo' cultivars on GF-677 when compared with Rootpac-20 (both trained in open-center).

The average kernel yield ranged from 29.5 to $38.33 \%$, similar to those reported by Puebla Arias et al. [52,53] (28.35-41.0\%) and somewhat higher than that found by Socias i Company et al. [26], who reported yields for 'Soleta' cultivar in the 27 to 35\% range, by Alonso Segura et al. [25] (30.4\%) and by Méndez [55] (32.4\% average yield over 6 years). Kernel yields were $\%$ higher in hedges in both growing seasons. It is worth noting that the highest yield corresponded to the SHD system in 2018, in which the kernel was proportionally larger compared to almond fruit in shell, despite being the one with the lowest weight of the four. Méndez [55] also observed this same behavior, in which the smallest fruits gave kernel yields higher than those of larger fruits. Nonetheless, the influence of other factors, such as the irrigation rate, cannot be excluded (e.g., Muhammad et al. [57] reported higher kernel weights for higher irrigation rates at similar fruit counts).

The canopy volume in the SHD system was considered fixed in each campaign, since pruning was carried out mechanically. The increase in volume in $2019\left(2.25 \mathrm{~m}^{3} \mathrm{vs} .2 .05 \mathrm{~m}^{3}\right)$ was due to the fact that the cutting height was raised (the width of the hedgerow remained constant). As for the differences in canopy volume in the open-center trees, they were due to differences in pruning, but both they were within usual values [55].

The yield per canopy volume ( $\mathrm{g}$ with hull $/ \mathrm{m}^{3}$ of canopy) in the open-center system was almost half that of SHD system (136 and $128 \mathrm{~g} / \mathrm{m}^{3}$ lower in 2018 and 2019, respectively; Table 2). This would be in agreement with Ben Yahmed et al. [39], who found that the use of low vigor rootstocks could be associated to a higher yield efficiency, widely reported in deciduous fruit species. This higher efficiency is important for the future evolution of the SHD system, since it indicates a more efficient use of light, with less shaded areas in the tree and with a canopy volume that is more quickly reached (i.e., it is more precocious). Both seasonal and cumulative yield of kernel per ha were consistently higher in the open-center than in the SHD system (2) because the spacing was close to the optimum in the case of the open-center/GF-677 but not in the SHD/Rootpac-20, as we described below.

With respect to the TCSA, the values for the open-center trees were very similar to those reported by Alonso Segura et al. [25] $\left(326.3 \mathrm{~cm}^{2}\right)$, but the reported yield efficiency, a widely used parameter for other fruit tree species (although not for almond trees), was much higher than those obtained in this study $\left(49.9 \mathrm{~g} / \mathrm{cm}^{2}\right)$. The lower TCSA values for the Rootpac-20 rootstock would be in agreement with Ben Yahmed et al. [39] and Lordan et al. [56], who studied the dwarfing effect through the significant slow growth of the trunk, finding that this rootstock would have $35-45 \%$ less vigor than GF677.

It is important to point out that in the present trial the first commercial/experimental orchard planted in world in SHD system in almond was analyzed. The spacing was $4 \mathrm{~m}$ (inter-row) $\times 1 \mathrm{~m}$ (intra-row), similar to the spacing used in apple orchards, corresponding to the so-called first version or V1. Afterwards, considering the latitude and the optimum ratio inter-row distance vs. tree height (1:1.1), inter-row spacing was first reduced to $3.5 \mathrm{~m}$ in a second version (V2), and then further reduced to $3.0 \mathrm{~m}$ inter-row spacing in the current version (V3). In the three versions (V1, V2 and V3), tree 
height was maintained in around $2.80 \mathrm{~m}$ and the intra-row distance in around $1.25 \mathrm{~m}$ in V2 and V3. Considering those distances, the mean yields obtained in commercial orchards in the 5th leaf have been 2103 and $2585 \mathrm{~kg}$ kernel/ha for V2 and V3, respectively [58].

There are advantages to closer planted trees other than earlier high yields in apple, pear and cherry. In peach, Núñez et al. [34] reported a direct relationship between yields and planting density. Trees planted more densely are smaller and it is easier to fully fill the canopy space. They are less likely to have scaffold breakage problems regardless of how they are trained (e.g., in aforementioned V2 and V3, trees are driven in a hedgerow system with multiple branching from the first year and disorganized canopy based on sequential summer prunings to train them without a central axis). They are less likely to blow over. If a tree dies, it has less of an impact on yield because there are more trees per acre. In our trial, the more closely planted trees were easier to prune (and may require less pruning) and did not show higher disease pressure.

Taking into consideration the agronomic performance data, and bearing in mind that further research with long-term follow-up is needed to confirm our observations, it may be put forward that the SHD system has a bright future ahead. As explained by Duncan [59] in relation to trials established in 2001 by University of California Cooperative Extension in Stanislaus County, "although some growers may feel that they need to space their trees far apart because of disease concerns, equipment access, ease of drying at harvest, etc. These are all valid reasons for wide spacings, but growers should understand they are sacrificing yield to do this. They may be necessary sacrifices, but they are sacrifices just the same".

\section{Conclusions}

In the present study, two almond-tree training systems, SHD and open-center, were compared under similar culture conditions during the 2018 and 2019 growing seasons. Fluorescence and SPAD analyses pointed to an adequate general health state of the plants in both systems and to an absence of stress. The analysis of light interception suggested the existence of areas in which light interception was very high for the open-center system, which may present problems with "sink leaves". Fruit set rates were similar in both training systems. The average almond in shell weight was significantly higher in the open-center system, while the fruit yield was significantly higher in the SHD one. It follows, then, that the SHD training system would be more efficient, although less productive, than the open-center system. However, the technical evolution of this new almond-tree training system has now led to a remarkable improvement in production efficiency, due to the reduction of inter-row distances and to the optimization of the occupation of the canopy by vegetation through an optimum training with respect to the system evaluated in the present study (V1). For this reason, and due to the advantages that this system presents in terms of management (reducing labor costs, especially for pruning and harvest), and efficiency on the use of inputs as water and phytosanitary treatments, efforts aimed at improving SHD system seem to be entirely justified.

Supplementary Materials: The following are available online at http://www.mdpi.com/2073-4395/9/12/874/s1, Figure S1: Location of the two plots of the experimental almond tree plantation; Figure S4: Evolution of PAR in the SHD system along a day in three different dates; Figure S5: Evolution of PAR in the open-center trained trees along a day in three different dates; Figure S6. Correlation circles from PCA analysis.

Author Contributions: Conceptualization, J.C.-G. and I.I.-C.; methodology, J.C.-G. and I.I.-C.; validation, J.C.-G., I.I.-C. and P.M.-R.; formal analysis, J.C.-G. and P.M.-R.; investigation, J.C.-G., M.F.-P. and P.M.-R.; resources, J.C.-G. and I.I.-C.; data curation, J.C.-G., M.F.-P. and P.M.-R.; writing-original draft preparation, J.C.-G., I.I.-C. and P.M.-R.; writing-review and editing, J.C.-G. and P.M.-R.; visualization, J.C.-G. and P.M.-R.; supervision, J.C.-G.; project administration, J.C.-G.; funding acquisition, J.C.-G. and I.I.-C.

Funding: This research was funded by Agromillora Iberia S.L.

Acknowledgments: The authors gratefully acknowledge José M. Roca-Farré for kindly providing the experimental plots in which the measurements were conducted, and to Lab-Ferrer (Lleida, Spain) for lending us the ceptometer user in this study. 
Conflicts of Interest: The authors declare no conflict of interest. The funders had no role in the design of the study; in the collection, analyses, or interpretation of data; in the writing of the manuscript, or in the decision to publish the results.

\section{References}

1. Consejería de Agricultura Pesca y Desarrollo Rural. Caracterización del sector de la almendra en Andalucía; Junta de Andalucía: Sevilla, Spain, 2016; p. 37.

2. MAPA. Estadísticas de superficies y producciones de cultivos. Available online: https://www.mapa.gob.es/ es/estadistica/temas/estadisticas-agrarias/agricultura/superficies-producciones-anuales-cultivos/ (accessed on 10 December 2019).

3. Miarnau, X.; Torgueti, L.; Batlle, I.; Romero, A.; Rovira, M.; Alegre, S. La revolución del almendro: Nuevas variedades y modelos productivos. In Proceedings of the Simposio nacional de almendro y otros frutos secos, Lérida, Spain, 24 September 2015; pp. 1-54.

4. Sansavini, S.; Neri, D.; Tombesi, A.; Continella, G.; Costa, G.; Ramina, A. Impiante e forme di allevamento, potatura, controllo de la fruttificazione e raccolta. In Arboricoltura Generale; Sansavini, S., Costa, G., Gucci, R., Inglese, P., Ramina, A., Xiloyannis, C., Eds.; Patron Editore: Bologna, Italy, 2012; pp. 333-398.

5. Famiani, P.; Proietti, E.; Lodolini, M.; Neri, D. L'Ulivo e l'Olio, Coltivazione: Gestione della chioma. In Coltura e Cultura; Angelini, R., Ed.; BayerCrop Science S.r.l.: Milano, Italy, 2008; pp. 389-411.

6. Arquero, O.; Belmonte, A.; Casado, B.; Cruz-Blanco, M.; Espadafor, M.; Fernández, J.; Gallego, J. Consejería de Agricultura, Pesca y Desarrollo Rural, Servicio de Publicaciones y Divulgación. In Manual del almendro; Junta de Andalucía: Sevilla, Spain, 2013; p. 78.

7. Iglesias, I. Evolución y desarrollo de sistemas de plantación superintensivos en cultivos leñosos. Vida Rural 2019, 472, 50-55.

8. Iglesias, I. Sistemas de plantación 2D: Una novedad en almendro, una realidad en frutales. Hacia una alta eficiencia. Revista de Fruticultura 2019, 67, 22-44.

9. Iglesias, I. Costes de producción, sistemas de formación y mecanización en frutales, con especial referencia al melocotonero. Revista de Fruticultura 2019, 69, 50-59.

10. Roca, J.M.; Gómez, J.M.; López, M. El almendro en seto SHD: La recolección con máquinas cabalgantes. Olint: Revista de plantaciones superintensivas de olivo 2014, 25, 35-47.

11. Pérez-Ruiz, M.; Rallo, P.; Jiménez, M.; Garrido-Izard, M.; Suárez, M.; Casanova, L.; Valero, C.; Martínez-Guanter, J.; Morales-Sillero, A. Evaluation of Over-The-Row Harvester Damage in a Super-High-Density Olive Orchard Using On-Board Sensing Techniques. Sensors 2018, 18, 1242. [CrossRef]

12. Goodwin, I.; Whitfield, D.M.; Connor, D.J. Effects of tree size on water use of peach (Prunus persica L. Batsch). Irrig. Sci. 2005, 24, 59-68. [CrossRef]

13. Williams, L.E.; Ayars, J.E. Grapevine water use and the crop coefficient are linear functions of the shaded area measured beneath the canopy. Agric. For. Meteorol. 2005, 132, 201-211. [CrossRef]

14. Wagenmakers, P.S.; Callesen, O. Influence of Light Interception on Apple Yield and Fruit Quality Related to Arrangement and Tree Height. Acta Hortic. 1989, 243, 149-158. [CrossRef]

15. Sander, G.F.; Macedo, T.A.; da Silva, P.S.; Welter, J.F.; Posser, A.J.; Rufato, L.; Kretzschmar, A.A. Effect of different training systems to catch greater light interception in apple cultivar Maxi Gala in temperate climate. Aust. J. Crop Sci. 2019, 13, 574-577. [CrossRef]

16. Tang, L.; Yin, D.; Chen, C.; Yu, D.; Han, W. Optimal Design of Plant Canopy Based on Light Interception: A Case Study With Loquat. Front. Plant. Sci. 2019, 10, 364. [CrossRef]

17. Raffo, M.D.; Iglesias, N. Efecto de la intercepción y distribución de la radiación fotosintéticamente activa en manzanos cv. Fuji, bajo cuatro sistemas de conducción en alta densidad. RIA. Revista de Investigaciones Agropecuarias 2004, 33, 29-42.

18. DeJong, T.; Day, K. Relationships between shoot productivity and leaf characteristics in peach canopies. HortScience 1991, 26, 1271-1273. [CrossRef]

19. Le Roux, X.; Sinoquet, H.; Vandame, M. Spatial distribution of leaf dry weight per area and leaf nitrogen concentration in relation to local radiation regime within an isolated tree crown. Tree Physiol. 1999, 19, 181-188. [CrossRef] [PubMed]

20. Felipe, A.J. El almendro: El material vegetal; Mira Editores: Zaragoza, Spain, 2000. 
21. Godini, A. Almond Fruitfulness and Role of Self-Fertility. Acta Hortic. 2002, 591, 191-203. [CrossRef]

22. Kester, D.; Griggs, W. Fruit setting in the almond: The effect of cross-pollinating various percentages of flowers and the pattern of flower and fruit drop. Proc. Am. Soc. Hortic. Sci. 1959, 74, 214-219.

23. Lampinen, B.; Dejong, T.; Weinbaum, S.; Metcalf, S.; Viveros, M. Spur dynamics and almond productivity. Options Méditerranéennes, Série A 2007, 63, 295-304.

24. Socias i Company, R.; Felipe, A.J. 'Belona' and 'Soleta' Almonds. HortScience 2007, 42, 704-706. [CrossRef]

25. Alonso Segura, J.M.; Socias i Company, R.; Kodad, O.; Espada Carbó, J.L.; Andreu Lahoz, J.; Escartín Santolaria, J. Performance of the CITA almond releases and some elite breeding selections. In Proceedings of the XVI GREMPA Meeting on Almonds and Pistachios, Meknes, Morocco, 12-14 May 2015; pp. 33-36.

26. Socias i Company, R.; Felipe Mansergas, A. 'Belona' y 'Soleta', dos nuevos cultivares de almendro. ITEA, información técnica económica agraria: revista de la Asociación Interprofesional para el Desarrollo Agrario 2006, 102, 398-421.

27. Socias i Company, R.; Alonso, J.M.; Kodad, O. Las heladas y las lluvias: Condicionantes climáticos para el almendro. Agricultura: Revista agropecuaria y ganadera 2009, 921, 626-630.

28. Stephenson, A.G. Flower and fruit abortion: Proximate causes and ultimate functions. Annu. Rev. Ecol. Syst. 1981, 12, 253-279. [CrossRef]

29. Valdebenito, D.; Tombesi, S.; Tixier, A.; Lampinen, B.; Brown, P.; Saa, S. Spur behavior in Almond trees (Prunus dulcis [Mill.] DAWebb): Effects of flowers, fruit, and "June drop" on leaf area, leaf nitrogen, spur survival and return bloom. Sci. Hortic. 2017, 215, 15-19. [CrossRef]

30. Espadafor, M.; Orgaz, F.; Testi, L.; Lorite, I.J.; Villalobos, F.J. Transpiration of young almond trees in relation to intercepted radiation. Irrig. Sci. 2015, 33, 265-275. [CrossRef]

31. Campillo, C.; Fortes, R.; Henar Prieto, M.D. Solar Radiation Effect on Crop Production. In Solar Radiation; Babatunder, E.B., Ed.; InTechOpen: London, UK, 2012; pp. 167-194. [CrossRef]

32. Connor, D.J. Towards optimal designs for hedgerow olive orchards. Aust. J. Agric. Res. 2006, 57. [CrossRef]

33. Iglesias, I.; Alegre, S. The effect of anti-hail nets on fruit protection, radiation, temperature, quality and profitability of 'Mondial Gala'apples. J. Appl. Hortic. 2006, 8, 91-100.

34. Núñez, R.; Iglesias i Castellarnau, I.; Montserrat Sangra, R.; Alegre Castellví, S. Eficiencia agronómica de seis sistemas de formación con la variedad de melocotón “Merrill O’Henry" (Prunus persica (Batsch)). ITEA, información técnica económica agraria: revista de la Asociación Interprofesional para el Desarrollo Agrario (AIDA) 2006, 102, 13-26.

35. Rosati, A. A Simple Method to Estimate Photosynthetic Radiation Use Efficiency of Canopies. Ann. Bot. 2004, 93, 567-574. [CrossRef]

36. Ranjbarfordoei, A.; Samson, R.; Van Damme, P. Photosynthesis performance in sweet almond [Prunus dulcis (Mill) D. Webb] exposed to supplemental UV-B radiation. Photosynthetica 2011, 49, 107-111. [CrossRef]

37. López-López, M.; Calderón, R.; González-Dugo, V.; Zarco-Tejada, P.; Fereres, E. Early detection and quantification of almond red leaf blotch using high-resolution hyperspectral and thermal imagery. Remote Sens. 2016, 8, 276. [CrossRef]

38. Erdal, Í.; Türkmen, R.; Akgün, A. Variations in chlorophyll, SPAD values and some nutrient concentrations depending on chlorosis in peach leaves. Lucrări Ştiinţifice 2016, 59, 13-16.

39. Ben Yahmed, J.; Ghrab, M.; Ben Mimoun, M. Eco-physiological evaluation of different scion-rootstock combinations of almond grown in Mediterranean conditions. Fruits 2016, 71, 185-193. [CrossRef]

40. Jiménez, S.; Pinochet, J.; Abadía, A.; Moreno, M.Á.; Gogorcena, Y. Tolerance response to iron chlorosis of Prunus selections as rootstocks. HortScience 2008, 43, 304-309. [CrossRef]

41. Lampinen, B.D.; Udompetaikul, V.; Browne, G.T.; Metcalf, S.G.; Stewart, W.L.; Contador, L.; Negrón, C.; Upadhyaya, S.K. A Mobile Platform for Measuring Canopy Photosynthetically Active Radiation Interception in Orchard Systems. HortTechnology 2012, 22, 237-244. [CrossRef]

42. Socias i Company, R.; Gradziel, T. Almonds: Botany, Production and Uses; CABI: Boston, MA, USA, 2017.

43. Kester, D.; Graziel, T. Almonds. In Fruit breeding, Nuts; Janick, J., Moore, J.N., Eds.; Wiley: New York, NY, USA, 1996; Volume 3, pp. 1-98.

44. Saa, S.; Brown, P.H. Fruit presence negatively affects photosynthesis by reducing leaf nitrogen in almond. Funct. Plant Biol. 2014, 41. [CrossRef]

45. Tombesi, S.; Lampinen, B.D.; Metcalf, S.; DeJong, T.M. Spur Fruit Set Is Negatively Related with Current-year Spur Leaf Area in Almond. HortScience 2015, 50, 322-325. [CrossRef] 
46. Martínez-Gómez, P.; Prudencio, A.S.; Gradziel, T.M.; Dicenta, F. The delay of flowering time in almond: A review of the combined effect of adaptation, mutation and breeding. Euphytica 2017, 213. [CrossRef]

47. Goldhamer, D.A.; Viveros, M. Effects of preharvest irrigation cutoff durations and postharvest water deprivation on almond tree performance. Irrig. Sci. 2000, 19, 125-131. [CrossRef]

48. Dorfman, J.; Dorfman, M.; Heien, D. Causes of almond yield variations. Calif. Agric. 1988, 42, 27-28.

49. Zarate-Valdez, J.L.; Muhammad, S.; Saa, S.; Lampinen, B.D.; Brown, P.H. Light interception, leaf nitrogen and yield prediction in almonds: A case study. Eur. J. Agron. 2015, 66, 1-7. [CrossRef]

50. Tombesi, S.; Lampinen, B.D.; Metcalf, S.; DeJong, T.M. Yield in almond is related more to the abundance of flowers than the relative number of flowers that set fruit. Calif. Agric. 2017, 71, 68-74. [CrossRef]

51. Kodad, O.; Socias i Company, R. Densidad floral, cuajado y características de los frutos del almendro en relación al tipo de ramificación. ITEA: Información Técnica Económica Agraria 2008, 104, 433-447.

52. Puebla Arias, M.; Vivas Cacho, A. Resultados de Estudio comparativo de variedades de almendro y nuevos modelos de producción. In Plantaciones en Seto; CICYTEX: Guadajira, Badajoz, 2015; p. 8.

53. Puebla Arias, M. Estudio comparativo de variedades de almendro y nuevos modelos de producción. In. Plantaciones en Seto; CICYTEX: Guadajira, Badajoz, 2016; p. 10.

54. Montañés, E. Datos productivos de las fincas pioneras en el almendro en alta densidad. Olint: Revista de plantaciones superintensivas de olivo 2016, 30, 52-55.

55. Méndez, J. Productividad de nuevas variedades de almendro en el Campo de Cartagena. In Informe Anual de Resultados; CDA Torre-Pachecho-CARM: Torre-Pachecho, Spain, 2018; p. 72.

56. Lordan, J.; Zazurca, L.; Maldonado, M.; Torguet, L.; Alegre, S.; Miarnau, X. Horticultural performance of 'Marinada' and 'Vairo' almond cultivars grown on a genetically diverse set of rootstocks. Sci. Hortic. 2019, 256. [CrossRef]

57. Muhammad, S.; Sanden, B.L.; Saa, S.; Lampinen, B.D.; Smart, D.R.; Shackel, K.A.; DeJong, T.M.; Brown, P.H. Optimization of nitrogen and potassium nutrition to improve yield and yield parameters of irrigated almond (Prunus dulcis (Mill.) D. A. webb). Sci. Hortic. 2018, 228, 204-212. [CrossRef]

58. Iglesias, I. El almendro en seto autoenraizado: Una nueva alternativa para los secanos. Horticultura 2019, 344, 24-33.

59. Duncan, R. Choosing the Correct Tree Spacing for Your Almond Orchard. Available online: http://cestanislaus. ucanr.edu/files/111776.pdf (accessed on 12 November 2019).

(C) 2019 by the authors. Licensee MDPI, Basel, Switzerland. This article is an open access article distributed under the terms and conditions of the Creative Commons Attribution (CC BY) license (http://creativecommons.org/licenses/by/4.0/). 